\title{
Policy Exceptionalism: analysis of ideational framework governing agricultural sector in Lithuania
}

\author{
Jonė Vitkauskaitė-Ramanauskienė \\ Stockholm University \\ Frescativägen, 11419 Stockholm, Sweden \\ cross' $^{\text {ref }}$ http://dx.doi.org/10.5755/j01.ppaa.19.3.26320
}

\begin{abstract}
After WWII, the agricultural sector emerged as an area of exception in western democracies and is often characterised by sector-specific policies, compartmentalised institutions, well-organised interests' groups and ideas explaining why this sector cannot be governed by freemarket forces. Nevertheless, over the last three decades, the sector has been reformed to incorporate neoliberal and environmental demands to a certain extent. Hence, the current agricultural regime consists of two competing discourses - policy exceptionalism versus post-exceptionalism. The study analyses this ideational struggle in the context of Lithuania. The study conducts interpretative discourse analysis of a site of discursive contestation, namely parliamentary debates over policy changes, which sparked farmers' unrest in Autumn, 2019. It is argued that policy exceptionalism is a dominant discourse governing Lithuanian agricultural sector and that it is maintained by the ruling party. Furthermore, it serves as a discursive barrier to the incorporation of environmental concerns into the agricultural policy-making process.
\end{abstract}

Keywords: Lithuanian agricultural policy, agriculture-environment nexus, policy exceptionalism, discourse analysis.

Raktažodžiai: Lietuvos žemès ūkio politika, žemès ūkio-aplinkosaugos ryšys, politikos išskirtinumas, diskurso analize.

\section{Introduction}

Agriculture has been an integral part of humanity for centuries. Nowadays, as the prime connection between people and the planet, it plays a huge role in all three aspects of sustainability economy, the wellbeing of society and the environment. Nevertheless, the progress of agricultural productivity comes with environmental costs. Scientists analysing agriculture-environment nexus stress the interconnectedness, interdependence, synergies, conflicts, and trade-offs between these two areas and call for an integrated governance approach to these policy domains (Liu et al., 2019; Fabiani et al., 2020). At the same time, they note that during the decision-making process, the environmental aspect is often undermined by agrarian agenda (Juntti, 2006). The reluctance of the agricultural sector to open up for the environmental domain might be explained by examining the ideational framework governing the agricultural regime.

The sector of agricultural policy is often described as exceptionalist (Grant, 1995). Agriculture emerged as an area of exception in Western countries after the Second World War and could be seen as a welfare state for the farm sector (Knudsen, 2009). What separated this sector from other domains was "a distinct set of sector-oriented institutions and ideas, well-organised and well-resourced sectoral interest groups, substantial government intervention in the market, and the potential for a significant redistribution of economic assets from the whole population (through taxes and higher consumer prices) to a relatively small group of producers and landowners" (Daugbjerg \& Feindt, 2017). 
Nevertheless, two trends, namely neoliberalism and environmental demands, emerged as a challenge to agricultural exceptionalism. Even though this sector has not yet been completely equalised with other domains, it has been reformed during the last three decades to incorporate these demands to a certain extent (Daugbjerg \& Feindt, 2017). Such an outcome is captured by what Daugbjerg and Feindt call agricultural post-exceptionalism. Hence, the current arrangement of the agricultural sector in Western democracies might be perceived as a struggle between two competing discourses - agricultural exceptionalism versus post-exceptionalism.

The tension between exceptionalist versus post-exceptionalist agricultural policy ideas can be captured by looking at European farmers' protests that took place in Autumn, 2019. Farmers in France protested against the European Union (E.U.) trade deals with Canada, which they saw as a source of unfair market competition. Farmers in Germany and the Netherlands found it hard to keep up with growing regulations aimed at protecting the environment and animals. Meanwhile, farmers' protests in Lithuania erupted after the Government and the President proposed a draft amendment to laws, of which three would have affected farmers through an increase in agricultural land tax, an increase in the excise duty rate on gas oil used for agricultural activities (i.e. green oil), and the abolition of excise relief on gas oil used for heating (i.e. red oil), which is often used by farmers to dry grains. The proposals were backed by post-exceptionalist policy reasoning - a need for all sectors to contribute to the next year's national budget, and a need to meet environmental goals. Therefore, they might be perceived as a 'threat' to the status quo maintained by the ruling party - Lithuanian Farmers' and Greens Union, which members are positioned to articulate the discourse keeping agricultural exceptionalism intact. To influence Parliamentary decisions in a favourable direction, protesters attempted to gain support from the society. Despite that, other groups of society did not express solidarity with the farmers. Nevertheless, the policy outcome of the parliamentary debates surrounding proposed changes favoured farmers' demands - all initial draft laws were rejected. In other words, the policy outcome kept the discourse of agricultural exceptionalism intact.

The aim of the study is to understand how agricultural exceptionalism is maintained and how it affects the position of environmental concerns in the agricultural policy decision-making process. It asks, why did the legislative body of the Lithuanian Government reject proposed policy changes and how has agricultural-exceptionalist policy outcome been achieved? As well as why were environmental concerns not reflected in the policy outcome of excise duties on gas oils? To shed light on the questions that are central to the debates on agricultural exceptionalism versus postexceptionalism, as well as agriculture-environment policy nexus, this study conducts interpretative discourse analysis of the parliamentary debates over policy changes, which sparked Lithuanian farmers' unrest in the Autumn, 2019.

The literature on the agriculture-environment policy nexus at the level of the CAP is vibrant (Alons, 2017; Juntti, 2006; Erjavec \& Erjavec, 2015). Nevertheless, few studies have analysed the role of actors' ideas in achieving a harmonised management of the agricultural and environmental policy domains at a national level (Stein \& Jespersen, 2019).

This study attempts to fill this gap by linking this issue to a broader ideational framework governing the agricultural sector, namely a struggle between exceptionalist and post-exceptionalist discourses. By doing so, it is argued that policy exceptionalism is a dominant discourse governing Lithuanian agricultural sector and that it serves as a discursive barrier to the incorporation of environmental concerns into the agricultural policy-making process.

\section{Theoretical Framework}

\section{Literature Review}

The concept of agricultural exceptionalism first appeared in Wyn Grant's work, where he compared characteristics of the agricultural sector to general trends of market liberalism (Grant, 1995). Overall, the literature analysing agriculture as an area of exception suggests that this policy 
domain distinguishes itself from the other sectors in several respects - policies, institutional arrangement, interests and ideas.

The agricultural sector is often characterised by sector-specific policies, such as ,,intervention buying by state agencies to stabilise producer prices, farm input subsidies, productionlinked direct payments, production quota to limit surplus production and maintain price levels or programs to enhance predefined environmental and conservation practices" (Daugbjerg \& Feindt, 2017). Furthermore, agriculture's exceptionalism is entrenched by compartmentalised institutional arrangement - special ministries, administrative bodies integrating farm associations, extension services, agricultural colleges and semi-state chambers of agriculture (Daugbjerg \& Feindt, 2017). Exceptionalist policies provide benefits to certain groups, which have a strong interest in keeping compartmentalised institutions intact. Hence, well-organised agricultural interests' groups are yet another component sustaining agricultural exceptionalism.

Finally, the core of agricultural exceptionalism is the articulation of ideas, explaining why this sector cannot be governed by free-market forces. There are three broad categories of ideas justifying the special treatment of this sector: 1) its exceptional vulnerability to unpredictable weather conditions, which causes instability in market prices and farmers' income; 2) low-income elasticity of food demand, which means that growing incomes of the consumers do not mean equally growing demand for agricultural products, hence, in order to earn more, farmers then seek to increase their output, which might result in decreased income if not enough workers leave the industry; 3) its contribution to the national interest and the welfare state (employment, income, safe food), its cultural and national values (Daugbjerg \& Feindt, 2017).

Nevertheless, two trends, namely neoliberalism and a demand to take agricultural ecological footprint under control, have emerged as a threat to agricultural exceptionalism. However, the extent to which different regions have incorporated these new concerns - differs. It is especially evident when comparing the agricultural sectors in the US and EU. Grace Skogstad argues that at the end of the XXth century, different ideas about agriculture's role in the economy and society started to be articulated in these continents, which influenced different policy outcomes - reforms in the US indicated a shift to the market liberalism, while the core goals of the CAP remained intact with an interventionist discourse (Skogstad, 1998).

These differences are noticeable in scholarly works on agricultural policy and looking for post-exceptionalist tendencies. The concept of post-exceptionalism refers to,"the combination of a less compartmentalised policy arena [...] with an updated set of policy ideas [...], albeit with updated arguments that relate to the problems on the evolving policy agenda and which trigger novel policy instruments" (Daugbjerg \& Feindt, 2017). For example, by examining lobbying of agricultural policy in the US, Adam Sheingate and colleagues found that groups from the banking industry, manufacturers of agricultural inputs, food processors, and the retail food sector significantly influence agricultural policy outcomes (Sheingate, 2017). It indicates the shift from the compartmentalised policy sector dominated by producer interests to more open, incorporating other demands policy domain (Sheingate, 2017).

Similar studies have been conducted in Europe. For example, Jale Tosun found that the biggest supporters of opening up policy-making in the agricultural sector to issues from other policy sectors are the green parties, while those more aligned with farmers supported weaker forms of postexceptionalism (Tosun, 2017). Furthermore, even though Alan Greer's study on CAP reforms of 2013 indicated changed institutional structures and actors as well as the incorporation of such issues as rural development, environmental sustainability and climate change, it also revealed that the impact of the policy has been limited, while the ideational framework of the CAP has not changed (Greer, 2017). Moreover, Gerry Alons proposes that limited transition from exceptionalism to postexceptionalism in associated institutional power and dominant ideas of the CAP hinders environmental policy integration (EPI) (Alons, 2017). In a similar vein, Simon J. Bulmer argues that agricultural policy-making in the EU was taking place in a vacuum due to isolated institutions of the CAP, hence did not include broader policy domains (e.g. environmental) (Bulmer, 2011). 
Meanwhile, discourse analysts have proven that this approach enables one to understand how the articulation of ideas creates obstacles for integrated governance of agricultural and environmental domains. For example, in her work on CAP mid-term review in 2003, Meri Juntti assessed the extent the introduction of the cross-compliance mechanism added to the greening of the agricultural sector (Juntti, 2006). She analysed how different actors constructed the aim of the crosscompliance mechanism as well as how decision-makers framed policy goals and found that agrarian and market-oriented agendas largely undermined the environmental protection aspect in the crosscompliance mechanism (Juntti, 2006). Furthermore, Karmen Erjavec and Emil Erjavec's work on the CAP reform (2014-2020) conducted a critical discourse analysis of documents and policy-makers' statements to show how key discourses (productivist, multi-functional and neo-liberal) were transformed by emphasising environmental element during the decision-making process (Erjavec \& Erjavec, 2015). Nevertheless, at the level of measures and budgetary distribution, the productivist discourse was dominant. Hence, a greening strategy was used as justification, while productivist discourse informed CAP measures (Erjavec \& Erjavec, 2015).

\section{Discourse}

The study employs Foucaultian conceptualisation of discourse. Michel Foucault was interested in the production of knowledge and meaning, not through language or discourse, as conceptualised by linguists, but rather through language as a practice of social process. Hence, discourse for Foucault was about both - language and practice. There are several distinctive traits of Foucaultian discourse analysis.

First, discourse physically shapes reality. In other words, objects and events are constructed through discourses. It is not to say that there is no material reality, but that our understanding of it is necessarily embedded in and conditioned by a discourse (Laclau \& Mouffe, 1985). Second, discourses are inseparable from specific historical conditions. Foucault saw discourse as a range of statements that provide a language with the way of talking about something, representing knowledge about a particular subject matter at a particular given historical juncture (Hall, 1992). Hence, discourses are never fully fixed, and they are always subject to change. He used term of épistémè (Foucault, 2002), which refers to historical conditions, that make certain discourses possible. In other words, épistémè is a way of interpreting reality, specific to a particular time. As Stuart Hall put it, "it is discourse, not the subjects who speak it, which produces knowledge; [subjects] may produce particular texts, but they are operating within the limits of the episteme, the discursive formation, the regime of truth of a particular period and culture" (Hall, 1997). Hence, discourse simultaneously enables certain interpretations of reality and subordinates others.

Third, concepts of power and knowledge are intertwined and central to Foucaultian discourse analysis. Foucault was interested in the form of power, which is not necessarily physical, but rather neutral, exercised by institutions and certain groups of people over society. Knowledge is used to exercise and legitimise power over subjects and objects. At the same time, power reproduce knowledge by shaping it in accordance with its anonymous intentions (Foucault, 1990). Knowledge linked to power has the ability to make itself 'true' (Foucault, 1977). Hence, by making knowledge claims, power can render certain subjects and objects governable. Therefore, knowledge for Foucault is a form of power. Nevertheless, power here should not be understood as centralised, absolute, seldom and stable. Foucault saw power relations as present in all forms of social interaction (Foucault, 1998). Furthermore, his take on the concept of power suggests that subjects can be the ones exercising power, as well as the ones being subjected to it (Foucault, 1982). In other words, actors are never entirely determined by a strategic situation (Feindt \& Oels, 2005).

Finally, In line with Foucaultian approach to discourse analysis, the concept of discourse in this study is understood as "an ensemble of ideas, concepts and categories through which meaning is given to social and physical phenomena, and which is produced and reproduced through an identifiable set of practices" (Hajer, 2006). 


\section{Hegemonic Struggle}

Due to the complexity of society, each policy sector has its structuring discourses (Scott, 2017). Certain discourses are subordinated, while others are dominant. Once used by many people to conceptualise the world, and institutionalised, discourse is said to be hegemonic (Hajer, 2006). Hence, institutions might be seen as sedimented discourses, i.e. "partially fixed systems of rules, norms, resources, practices and subjectivities that are linked together in particular ways" (Howardth, 2009). Nevertheless, even hegemonic discourses are never fully fixed. Therefore, during the policy decision-making process, various actors seek to sustain existing or establish new discourses as dominant in order "to establish a dominant political 'truth' that in turn legitimises societal intervention strategies by means of policies and policy instruments" (Winkel \& Leipold, 2016). To do so, actors make claims to legitimise knowledge on which 'their' discourses are based (Scott, 2017). Such a process of argumentation might be understood as a "struggle for discursive hegemony in which actors try to secure support for their definition of reality" (Hajer, 1995). One or several discourses that become dominant during the decision-making process, then reflect in institutional practices. Hence, public policy is a product of argumentation.

In this case, after the Government and the President proposed post-exceptionalist policy changes to the agricultural sector, it indicated that the establishment split up into two competing frontiers - those supporting the deprioritisation of the sector (i.e. executive power) and those seeking to maintain the status quo (e.g. the ruling party). Therefore, here hegemonic struggle is understood as taking place between actors articulating these competing discourses.

\section{Storylines and Discourse Coalitions}

Storyline is "a condensed sort of narrative that connects different discourses" (Hajer, 2005). It is used as a tool to create new, and sustain existing discursive order. By incorporating different discourses, storylines summarise various complex components of a problem and allow people to understand and explain complicated issues (Hajer, 1995). They are used as 'shorthand' by people in a discussion (Hajer, 2006). Hence, storylines are produced by people articulating various discourses during the debate. Storylines are important because they are employed by actors to represent their arguments in an understandable, persuading and appealing way, and so gain success in the eye of an audience.

In a sense, the 'success' of a storyline is determined upon its ability to incorporate as many elements of various discourses as possible. It is so because the more discourses subscribe to the specific storyline, the stronger a discourse coalition becomes. The discourse coalition is defined as "a group of actors that, in the context of an identifiable set of practices, shares the usage of a particular set of storylines over a particular period of time" (Hajer, 2006). Formation of the discursive coalition gives relatively more importance to a particular view during the decision-making process and has the potential to become institutionalised with further enlargement of the discursive coalition (Brosius, 1999).

\section{Material and Method}

The analysis focused on the debates surrounding the draft laws suggesting an increase in agricultural land tax (Land tax law no. I-2675, No XIIIP-4021), increase in the excise duty rate on gas oil used for agricultural activities, and annulation of excise relief on gas oil used for heating (Excise duty no. IX-569 Bill No. XIIIP-4018 (2)). Selection of draft laws followed certain criteria for inclusion and exclusion. First, these were the reforms over which farmers' protests erupted. Hence, they were seen as a threat to agricultural exceptionalism, while debates surrounding them, were expected to reflect the tension between exceptionalist versus post-exceptionalist policy ideas. Second, there has been a third reform proposed by the Government, which caused farmers' dissatisfaction increase in income and social security tax for self-employed persons (Personal Income Tax Act 
no. IX-1007, No. XIIIP-3953). Even though farmers often use self-employment as a form of activity, debates surrounding this specific reform were not analysed. This policy instrument was not expected to reflect tensions between exceptionalist versus post-exceptionalist policy ideas - various other stakeholder groups could have been affected by the reform (e.g. performers, writers, etc.).

The empirical material was extracted from the official YouTube channel of the Lithuanian Parliament - https://www.youtube.com/user/LTSeimastiesiogiai/featured. Parliamentary, as well as committees' debates over selected draft laws, were accessible on this channel. In total there were four Parliamentary debates, which took place on October 22, November 21, November 26 and December 3. Furthermore, there were two meetings of the Committee on Rural Affairs on October 23 and November 6; one meeting of the State Management and Municipal Committee on November 5; and three meetings of the Committee on Budgets and Finance on November 13, 20 and December 3. All of the Parliamentary and committees' meetings were analysed, except for the last meeting of Committee on Budgets and Finance, which took place on December 3, because the broadcast was unavailable at the time of the research.

All the statements concerning selected articles expressed during the parliamentary hearings and appointed committees' meetings were transcribed. Transcribed debates were coded twice. First time research material was coded deductively. All the statements were assigned to one of the following categories - 'supporting policy change' and 'against policy change'. It was assumed that statements falling under the first category represent post-exceptionalist policy discourse, while statements placed under the second category, represent exceptionalist policy discourse.

The second time research material was coded inductively. Four distinct representations of the proposed policy changes emerged from the research material. Each representation distinguished itself by certain framing devices. Hence, by looking for particular framing devices drawn from a common conceptual domain, statements were assigned to one of the representations/storylines. The following are four overarching storylines that emerged during the parliamentary debates, as well as conceptual domains common to them:

- Distribution of the policy costs - outcomes of proposed changes were discussed through the lens of the economic effect on different groups of society. According to this storyline, no matter what, policy outcomes would have a financial effect on unintended groups of society. Framing devices common to such representation were 'increase in costs', 'increase in prices', 'decrease in a budget', 'effect on consumers', 'effect on retirees', 'effect on small-scale farmers'.

- Agricultural exceptionalism - proposed policy changes were discussed through the lens of a wider framework of the agricultural sector. In other words, proposed policy changes were positioned in a broader context of the agricultural sector. Framing devices common to such representation were 'benefits', 'uncompetitive', 'reputation of farmers', 'hard-working', 'respect', 'accusations', 'weather conditions', 'direct payments', 'disappearing dairy farms'.

- Environmental dimension - proposed policy changes were discussed through the lens of environmental protection. This storyline acknowledged and incorporated the dimension of the environment. Framing devices common to such representation were 'pollution', 'environmental objectives', 'climate change', 'renewable energy', 'nature', 'environmental standards', 'environmental requirements'.

- Obligation to constituents - proposed policy changes were discussed through the lens of governing bodies' obligations to their constituents. This storyline introduced a dimension of morality. According to this storyline, proposed policy changes were morally unjust. Framing devices common to such representation were 'obligations', 'deception', 'confrontation', 'honour', 'keep one's faith', 'urban-rural confrontation'.

Finally, Discourse coalitions were identified by looking where actors representing competing discourses used the same conceptual domain to describe the issue at hand. The following section discusses each storyline separately. The discussion draws upon debates' material. 


\section{Results}

\section{Storyline: Distribution of the Policy Costs}

The first emergent storyline concerned the distribution of policy costs among society. Both sides articulating competing discourses subscribed to this storyline. 'Post-exceptionalist policy' camp (Gintare Skaistè, Mykolas Majauskas) employed this storyline during the debates over the excise duty rate on gas oil used for agricultural activities. Those supporting the proposed change subscribed to the Government's reasoning that an increase in the excise duty rate on gas oil used in agricultural activities, is necessary to collect enough money to the next year's national budget and to increase pensions. Hence, it was argued that if the proposal to increase excise duty rate on green oil was rejected, it would result in a gap in the next year's budget, which would have to be filled in any case. In other words, costs would be distributed among other groups of society. The following quote illustrates this argument:

"The proposal of the Committee on Rural Affairs [to reject the Government's and
the President's proposal to increase excise duty rate on gas oil used in agricultural
activities either by 45 or 160 per cent] was approved, which will result in an
increase in excise revenue of precisely by 1 million Eur. Meanwhile, the
Government's proposal was to generate 6.5 million and the President's proposal -
17 million Eur budget revenue. I just want to point out that this bill, after being
modified by a decision of the Budget and Finance Committee, will generate 20.3
million Eur less budget revenue than the Government had planned. And the
expenditure of the state budget will have to be reduced accordingly."

Gintare Skaiste commenting on the excise duties' project during the parliamentary hearing, after the first round of committees' meetings. November

21,2019

Meanwhile, 'exceptionalist policy’ camp (Edmundas Pupinis, Remigijus Žemaitaitis, Juozas Baublys, Vida Ačienè, Valius Ąžuolas, Bronius Bradauskas, Andriejus Stančikas, Kazys Starkevičius) employed this storyline to argue that instead of being disadvantageous for farmers, proposed measures would negatively affect other groups of society. The opposition of proposed policy changes evoked this argument throughout the debates over all three measures. The first social strata, which was mentioned by 'exceptionalist policy' camp as possibly experiencing financial burden caused by the policy changes, was that of consumers:

"You now think that these increases will not be reflected in the price of agricultural produce. It goes without saying that it [higher tax] will be transferred in the cost, and those who consume food will pay for it."

Edmundas Pupinis commenting on agricultural land tax. October 22, 2019

The second group, which was distinguished by 'exceptionalist policy' camp as possibly experiencing the burden of the proposed measures was retirees. Despite the fact that these changes were proposed as necessary measures to reduce poverty among pensioners, those opposing the proposals framed changes as potentially having the opposite effect:

"It must not be forgotten that if we accept it as it is proposed, it will still increase the prime cost of the [agricultural] products [...]. And, of course, food prices. What is a benefit for retirees if pensions are increased, but at the same time they pay more for food? The main part of the pension is devoted to food."

Vida Ačienė commenting on excise duty on green oil. November 13, 2019

Finally, the last group, which was repetitive in the 'exceptionalist policy' camp's argumentation, that proposed policy changes would generate financial burden for unanticipated 
groups, was small-scale farmers. Such argumentation emerged during the debates over excise duties on green and red oils. It was argued that large-scale agricultural companies were able to pay higher prices for green oil as well as dry grains using gas instead of red oil. Meanwhile, small-scale farmers were the ones who would be mostly affected, since they are not as profitable, and because they dry grains using red oil:

"Fuel excise duty is paid by both - those who get profit and those who do not. By everyone. And [it will mainly affect] those small 100,000 farmers."

Valius Ąžuolas commenting on excise duty on green oil. November 13, 2019

In conclusion, actors articulating different discourses subscribed to this storyline to frame the issue at hand as affecting a wider population. In doing so, the circle of interest over the proposed policy changes was expanded - it was no longer confined only to farmers' strata. Once policies were presented as relevant to the other groups of the society, it became possible for various interests to be linked to one of the competing discourses. 'Post-exceptionalist policy' camp expanded the circle of interest to the whole society. It provided a very broad 'discursive umbrella', to which, interests of all groups of the society could potentially be related. Meanwhile, 'exceptionalist policy' camp expanded the circle of interests to the following groups - consumers, retirees and small-scale farmers. It provided focal points for the specific groups' interests to be linked to. Nevertheless, considerably more members from the 'exceptionalist policy' camp articulated this storyline (see table 1). Consequently, the discourse of agricultural exceptionalism was reinforced through this storyline.

\section{Storyline: Agricultural Exceptionalism}

The second emergent storyline concerned the wider framework of the agricultural sector. Both sides articulating competing discourses subscribed to this storyline. 'Post-exceptionalist policy' camp (Justas Džiugelis, Mykolas Majauskas, Prezidentūra, Aušrinè Armonaitė) employed this storyline during the debates over agricultural land tax and excise duty on green oil. Those supporting the proposed changes, highlighted the exceptional treatment of the agricultural sector, its negative consequences for the economy, and hence, framed proposed measures as necessary tools to move away from such exceptionalist arrangement. It was argued that the sector is uncompetitive due to the vast array of exemptions it enjoys. Furthermore, it was pointed out that the excise duty rate on green fuel is the lowest in Europe, and so this exemption adds to the shadow economy because the green fuel is often used not for intended purposes ${ }^{1}$. The following statements lay out the key arguments expressed to support this side of the sub-storyline:

"I would like to point out that in general farmers enjoy almost eighteen benefits [...] Therefore, at this stage, I invite you to support the bill."

Justas Džiugelis commenting on agricultural land tax. October 22, 2019

"And if they [farmers] are already supported, then perhaps they should be supported more through controlled mechanisms. Because controlling how much and what kind of labeled [green] diesel is used now and where it is being used, or not actually being used for personal use, seems to me quite difficult."

Mykolas Majauskas commenting on excise duty on green oil. November 13,

2019

\footnotetext{
${ }^{1}$ The purchase of green oil is regulated by law - persons wishing to purchase this fuel must have a relevant permit. Their issuance and control is administered by the State Tax Inspectorate (STI). Nevertheless, sometimes farmers abuse this benefit and sell green oil in a shadow economy.
} 
Meanwhile, 'exceptionalist policy' camp (Jurgis Razma, Edmundas Pupinis, Ministry of Agriculture, Juozas Baublys, Petras Čimbaras, Andriejus Stančikas, Andrius Palionis, Viktoras Rinkevičius, Vida Ačienė, Tomas Tomilinas, Bronius Bradauskas, Lithuanian Agriculture Council, Kazys Starkevičius) employed this storyline to argue that farmers' reputation was damaged. It was argued that farmers were being presented as rich, dependents and receiving many benefits. To redeem the 'good reputation' of farmers, they sought to diminish such a negative depiction. Instead, farmers were presented as 'hard-working', 'taking risks' and 'creating jobs':

“...in fact, the reputation of farmers has never been damaged as it is now. There are thousands and hundreds of thousands of people who work hard on their family farms and earn a decent living."

Edmundas Pupinis commenting on agricultural land tax. October 22, 2019

Furthermore, 'exceptionalist policy' camp articulated ideas justifying exceptionalist treatment of the agricultural sector. Arguments were in line with three types of exceptionalist justifications distinguished by Daugbjerg and Feidt (2017). It was argued that such exemptions as lower agricultural tax or excise relief on green oil, are crucial for the survival of the sector. Moreover, it was argued that such factors as low direct payments from the EU and adverse climatic conditions add to uncompetitiveness of the agricultural sector, which in turn results in disappearing farms. The following statements possess all components of the argument:

"It seems that this ruling political force, with its many farmers, should see how difficult the situation is in agriculture. When output falls due to unfavourable conditions; when [equalising] our direct payments to those of the older European countries, is only a distant mirage; when dairy farms are disappearing; and here one can continue and continue."

Jurgis Razma commenting on agricultural land tax. November 26, 2019.

In conclusion, by employing this storyline, actors positioned the proposed policy changes in a wider ideational framework governing the agricultural sector. Both sides aligned the representation of the agricultural sector according to the discourses they articulated. By describing the agricultural sector as already 'enjoying many benefits', 'post-exceptionalist policy' camp represented it as 'appropriate' to cut some of these benefits from. Furthermore, by describing the sector as 'uncompetitive' due to these benefits, proposed policy changes were presented as necessary measures to improve the functioning of the sector. Hence, beneficial for the sector itself. Meanwhile, 'exceptionalist policy' camp framed the agricultural sector as 'unsuitable' to collect revenue from and presented farmers as 'hard-working', yet 'disrespected'. Hence, 'post-exceptionalist policy' camp's depiction of the agricultural sector was presented as 'an insult' to farmers. Moreover, by evoking three types of exceptionalist justifications by (Daugbjerg \& Feidt, 2017), the benefits of the agricultural sector were presented as reasonable and necessary. Finally, this storyline was articulated by more members from 'exceptionalist policy' camp than from the opposite one (see table 1). Consequently, the discourse of agricultural exceptionalism was reinforced through this storyline.

\section{Storyline: Environmental Dimension}

Two of three policy measures (excise duty rates on green and red oils) that are the focus of this study contain environmental aspect. Green and red oils are fossil fuels, which both have a considerable environmental footprint. Hence, the third emergent storyline concerned the environmental dimension of exemptions for gas oils used in agricultural activities, namely green and red oils. Both sides of the discursive spectrum presented competing framings of the environmental aspect of proposed measures. 'Post-exceptionalist policy' camp (Mykolas Majauskas, Ministry of Finance, Ministry of Energy) framed the current exemptions for green and red oils, as contradicting 
environmental goals. According to this framing, an increase in the excise duty rate on green oil and annulling the excise relief on red oil, were necessary measures to meet environmental goals:

"...we support fossil fuels with this exemption. If we are talking about reducing pollution, then there seems to be an inconsistent stance."

Mykolas Majauskas commenting on excise duty on green oil. November 13,

2019.

Meanwhile, 'exceptionalist policy' camp (Andrius Palionis, Viktoras Rinkevičius, Kazys Starkevičius, Lithuanian Agriculture Council) employed this storyline only as a response to the 'postexceptionalist policy' camp's argumentation that these measures were necessary for the environmental protection. Such framing was weakened by two types of argumentation. First, gas oils were presented as 'better' for the environment in comparison to other types of fuel:

„Now, as you say, this fuel is designed to fight pollution. You are entirely wrong.

All other fuels - firewood, coal are more polluting to nature."

Kazys Starkevičius commenting on excise duty on red oil. October 23, 2019.

Second, on the one hand, agriculture was presented as already contributing to environmental protection by complying with all the requirements foreseen in the level of the EU. On the other hand, environmental measures that have already been introduced in the agricultural sector, were shaped as a burden to the sector. The following arguments illustrate both sides of the argumentation:

“...let us not forget that our farmers are paying 15-20\% more for the current new technology, as it is in line with the new [environmental] standards..."

Minister of Agriculture Andrius Palionis commenting on excise duty on green oil. November 13, 2019.

“...requirements - environmental, technological, and others - throughout the EU, are more or less the same and we must comply. Meanwhile, as we mentioned, the support we receive is one of the lowest, which is why let's just stop talking about that topic [increase in excise duty rate for gas oil used in agricultural activities]."

Viktoras Rinkevičius commenting on excise duty on green oil. November 13,

2019.

In conclusion, actors articulating different discourses subscribed to this storyline to discuss the issue of gas oils through the lens of environmental protection. This storyline was first generated by the 'post-exceptionalist policy' camp. Proposed changes to gas oils policy were framed as necessary to meet environmental goals. Meanwhile, the 'exceptionalist policy' camp discussed the environmental aspect of gas oils only as a response to the unfavourable presentation of agriculture's commitments to environmental protection. First, it was argued that the agricultural sector is already implementing all the mandatory environmental measures. Hence, the environmental justification of proposed changes was presented as insufficient. Furthermore, the proposed changes to gas oil policies were presented as unnecessary. Second, by evoking the argument of additional costs of environmental measures, that have already been introduced in agricultural activities, proposed changes were framed as yet another source of the financial burden to farmers. This finding is in line with those found in the academic literature on agriculture-environment policy nexus, that environmental protection is often undermined by agrarian agenda (Juntti, 2006; Erjavec \& Erjavec, 2015). The number of actors articulating this storyline was quite even among competing discursive camps (see table 1). Nevertheless, while comparing the number of MPs employing this storyline, it is noticeable that 'exceptionalist policy' camp's framing of the environmental aspect, was more favoured by the actors with legislative power, rather than those from the executive power. Consequently, it gave agricultural 
exceptionalism's discourse an advantage during the voting. Therefore, it can be said that agricultural exceptionalism was again reinforced through this storyline.

\section{Storyline: Obligation to Constituents}

The fourth emergent storyline concerned the obligations of the governing bodies to their constituents. This storyline was employed throughout the debates concerning all three measures. Nevertheless, only 'exceptionalist policy' camp (Lithuanian Agriculture Council, Rasa Petrauskienè, Algimantas Salamakinas, Farmers' Self - Government) subscribed to it. First, it was argued that such authorities as municipalities and MPs, do not want to increase the financial burden for their constituents. Such intention was framed as 'care' for their electorate's being:

"Municipalities do not want to raise more taxes, they want to fulfil their obligations to their constituents, residents of their district, and not to increase that tax. And here is the Government that decides for those people who live in villages, in rural areas. And they make decisions without considering their wishes at all."

Chairman of Lithuanian Agricultural Council Aušrys Macijauskas commenting on agricultural land tax. November 20, 2019.

On the contrary, those authorities, which proposed the changes were presented as 'not following the word':

"Best regards to the President from the countryside and from the farmers. It was not mentioned during the election campaign that "we are coming and raising [taxes], reducing exemptions' [...]. That was not said. The village was deceived.”

A representative of the Farmers' Self - Government commenting on excise duty on green oil. October 23, 2019.

Second, the reason behind the proposed changes (to collect enough money to the next year's national budget in order to raise pensions) was framed as complicating politicians' function to serve their constituency. Such framing was based on an argument that the proposal confronts two strata of society or two groups of the electorate, and places decision-makers in an 'awkward' position between these social groups:

"Why do we want to oppose several strata of people - retirees with teachers, farmers with retirees and so on? [...] Now you are taking from the farmer, and saying that you will give to the retiree. Now you are placing us [politicians] in such a position - if we do not take from the farmer [...], the retirees will not get it [higher pensions]. Then, we go to the county and the retiree says - and why didn't you take from the farmer? Meanwhile, farmers are behind us. And how to take from them, if they also do not have much? [...]Why do you confront us with a certain class of people?"

Algimantas Salamakinas commenting on excise duty on green oil. October 23, 2019.

In conclusion, actors articulating discourse of agricultural exceptionalism, subscribed to this storyline to frame proposed policy changes as morally unjust. It was done through a couple of mechanisms. First, authorities supporting proposed policy changes were presented as 'not complying with obligations to constituents'. Meanwhile, those opposing proposed policy changes were presented as an opposite to that. Second, the aim of proposed policy changes was framed as 'dividing society' and placing policy-makers into a moral dilemma of which social strata to favour. This storyline was evoked by 'exceptionalist policy' camp throughout debates concerning all three measures. None of the actors articulating competing discourse subscribed to this storyline. Therefore, agricultural exceptionalism was again reinforced through this storyline. 
Table 1. Storylines and associated discourse coalitions

\begin{tabular}{|c|c|c|}
\hline Storyline & Key values and attitudes & Contrasting discourse coalition memberships \\
\hline $\begin{array}{l}\text { Distribution of } \\
\text { the policy costs }\end{array}$ & $\begin{array}{l}\text { Policy changes were framed as affecting the } \\
\text { interests of a wider population. 'Post- } \\
\text { exceptionalist policy' camp employed the } \\
\text { storyline to include the interests of the whole } \\
\text { society. 'Exceptionalist policy' camp } \\
\text { employed the storyline to include the } \\
\text { interests of specific groups. }\end{array}$ & $\begin{array}{l}\text { 'Post-exceptionalist policy' camp: Gintarè } \\
\text { Skaistė, Mykolas Majauskas } \\
\text { 'Exceptionalist policy' camp: Edmundas } \\
\text { Pupinis, Remigijus Žemaitaitis, Juozas Baublys, } \\
\text { Vida Ačienė, Valius Ažuolas, Bronius } \\
\text { Bradauskas, Andriejus Stančikas, Kazys } \\
\text { Starkevičius }\end{array}$ \\
\hline $\begin{array}{l}\text { Agricultural } \\
\text { exceptionalism }\end{array}$ & $\begin{array}{l}\text { Policy changes were positioned in a wider } \\
\text { ideational framework of the agricultural } \\
\text { sector. 'Post-exceptionalist policy' camp } \\
\text { employed the storyline to represent the } \\
\text { agricultural sector as 'needing' proposed } \\
\text { changes. 'Exceptionalist policy' camp } \\
\text { employed the storyline to represent the } \\
\text { agricultural sector as 'unsuitable' to collect } \\
\text { revenue from. }\end{array}$ & $\begin{array}{l}\text { 'Post-exceptionalist policy' camp: Justas } \\
\text { Džiugelis, Mykolas Majauskas, Presidency, } \\
\text { Aušrine Armonaite } \\
\text { 'Exceptionalist policy' camp: Jurgis Razma, } \\
\text { Edmundas Pupinis, Ministry of Agriculture, } \\
\text { Juozas Baublys, Petras Čimbaras, Andriejus } \\
\text { Stančikas, Andrius Palionis, Viktoras } \\
\text { Rinkevičius, Vida Ačienė, Tomas Tomilinas, } \\
\text { Bronius Bradauskas, Lithuanian Agriculture } \\
\text { Council, Kazys Starkevičius }\end{array}$ \\
\hline $\begin{array}{l}\text { Environmental } \\
\text { dimension }\end{array}$ & $\begin{array}{l}\text { Policy changes were discussed through the } \\
\text { lens of environmental protection. 'Post- } \\
\text { exceptionalist policy' camp employed the } \\
\text { storyline to represent the gas oils' policy } \\
\text { changes as necessary for environmental } \\
\text { protection. 'Exceptionalist policy' camp } \\
\text { employed the storyline to represent current } \\
\text { agriculture's commitment to environmental } \\
\text { protection as already sufficient. Furthermore, } \\
\text { environmental measures were framed as a } \\
\text { financial burden. }\end{array}$ & $\begin{array}{l}\text { 'Post-exceptionalist policy' camp: Mykolas } \\
\text { Majauskas, Finance Ministry, Ministry of } \\
\text { Energy } \\
\text { 'Exceptionalist policy' camp: Andrius } \\
\text { Palionis, Viktoras Rinkevičius, Kazys } \\
\text { Starkevičius, Lithuanian Agriculture Council }\end{array}$ \\
\hline $\begin{array}{l}\text { Obligation to } \\
\text { constituents }\end{array}$ & $\begin{array}{l}\text { Policy changes were presented as morally } \\
\text { unjust. Only 'exceptionalist policy' camp } \\
\text { employed this storyline. First, authorities } \\
\text { supporting proposed policy changes were } \\
\text { presented as 'not complying with obligations } \\
\text { to constituents'. Second, the aim of proposed } \\
\text { policy changes was framed as 'dividing } \\
\text { society' and placing policy-makers into a } \\
\text { moral dilemma of which social strata to } \\
\text { favour. }\end{array}$ & $\begin{array}{l}\text { 'Exceptionalist policy' camp: Lithuanian } \\
\text { Agriculture Council, Rasa Petrauskienė, } \\
\text { Algimantas Salamakinas, Farmers' Self - } \\
\text { Government }\end{array}$ \\
\hline
\end{tabular}

Source: Authors.

\section{Conclusions}

The aim of the study was to understand how agricultural exceptionalism is maintained and how it affects the position of environmental concerns in the agricultural policy decision-making process. The study conducted an interpretative discourse analysis of Parliamentary debates over policy changes, which sparked farmers' unreset. It sought to answer why did the Lithuanian Parliament reject proposed policy changes and how has agricultural-exceptionalist policy outcome been achieved? Moreover, why were environmental concerns not reflected in the policy outcome of excise duties on gas oils? 
It was found that Parliament rejected proposed policy changes because actors articulating discourse of agricultural exceptionalism managed to reinforce it through emerging storylines more 'successfully'. In other words, more actors articulated agricultural exceptionalist framing of the storylines than those articulating post-exceptionalist policy discourse. Agricultural-exceptionalist policy outcome has been achieved through the following framing devices - proposed policy changes were presented as unfavourable to wider groups of the society and morally unjust; agricultural sector was framed as 'unsuitable' to collect revenue from; environmental measures were presented as a financial burden.

These findings suggest that the discourse of agricultural exceptionalism was maintained in the establishment even though the executive power challenged its dominance by proposing postexceptionalist policy changes. Furthermore, it suggests that the discourse of policy exceptionalism governs the agricultural decision-making process in Lithuania. It is in line with the academic literature, which argues that despite post-exceptionalist concerns being linked to the sector, exceptionalist ideas are at the core of the claims surrounding agricultural policy-making (Greer, 2017; Alons, 2017). Moreover, one of the unanticipated (nevertheless unsurprising) findings of the study is that agricultural exceptionalism is mostly articulated by the members of Lithuanian Farmers' and Greens' Union (see Annex). This observation is in line with Jale Tosun's finding that political parties, which are more aligned with farmers, are least supportive of post-exceptionalist policies (Tosun, 2017). Given that this party has a parliamentary majority, it is unlikely that a shift in the ideas governing the agricultural sector will occur before the ruling majority is replaced.

Finally, because of the discourse dominating agricultural policy-making, namely agricultural exceptionalism, environmental concerns were not reflected in the policy outcome of excise duties on gas oils. In line with Gerry Alons' finding that limited transition from exceptionalism to postexceptionalism in institutional power and dominant ideas of the CAP resulted in limited environmental policy integration (Alons, 2017), this study found that dominant ideas, justifying sector-oriented policies, hindered incorporation of environmental concerns into agricultural policy debates in Lithuania.

This finding contributes to the literature on agriculture-environment policy nexus, which suggests that the integrated governance of these two domains has not yet been achieved due to agriculture's prioritisation over environmental protection (Juntti, 2006; Erjavec \& Erjavec, 2015). By linking this issue to a broader ideational framework governing the agricultural sector, this study showed how the prioritisation of the agrarian agenda is sustained. 


\section{Annex}

Actors articulating contrasting discourses.

\begin{tabular}{|c|c|c|}
\hline & Name & Political Party Membership \\
\hline \multirow{7}{*}{$\begin{array}{l}\text { 'Post- } \\
\text { exceptionalist } \\
\text { policy' camp }\end{array}$} & Gintarè Skaistė & $\begin{array}{l}\text { Homeland Union-Lithuanian Christian Democrats (opposition/centre } \\
\text { right) }\end{array}$ \\
\hline & Mykolas Majauskas & $\begin{array}{l}\text { Homeland Union-Lithuanian Christian Democrats (opposition/centre } \\
\text { right) }\end{array}$ \\
\hline & Justas Džiugelis & $\begin{array}{l}\text { Homeland Union-Lithuanian Christian Democrats (opposition/centre } \\
\text { right) }\end{array}$ \\
\hline & Presidency & \\
\hline & Aušrinè Armonaitè & A mixed group of MPs \\
\hline & Finance Ministry & \\
\hline & Ministry of Energy & \\
\hline \multirow[t]{18}{*}{$\begin{array}{l}\text { 'Exceptionalist } \\
\text { policy' camp }\end{array}$} & Edmundas Pupinis & $\begin{array}{l}\text { Homeland Union-Lithuanian Christian Democrats (opposition/centre } \\
\text { right) }\end{array}$ \\
\hline & Remigijus Žemaitaitis & A mixed group of MPs \\
\hline & Juozas Baublys & $\begin{array}{l}\text { Liberal Movement of the Republic of Lithuania (opposition/centre } \\
\text { right) }\end{array}$ \\
\hline & Vida Ačienè & Lithuanian Farmers' and Greens' Union (major party/ centre-left) \\
\hline & Valius Ąžuolas & Lithuanian Farmers' and Greens' Union (major party/ centre-left) \\
\hline & Bronius Bradauskas & Social Democratic Party of Lithuania (opposition/centre-left) \\
\hline & Andriejus Stančikas & Lithuanian Farmers' and Greens' Union (major party/ centre-left) \\
\hline & Kazys Starkevičius & $\begin{array}{l}\text { Homeland Union-Lithuanian Christian Democrats (opposition/centre } \\
\text { right) }\end{array}$ \\
\hline & Jurgis Razma & $\begin{array}{l}\text { Homeland Union-Lithuanian Christian Democrats (opposition/centre } \\
\text { right) }\end{array}$ \\
\hline & Ministry of Agriculture & \\
\hline & Petras Čimbaras & A mixed group of MPs \\
\hline & Andrius Palionis & $\begin{array}{l}\text { Social Democratic Labour Party of Lithuania (ruling coalition/centre } \\
\text { (left)) }\end{array}$ \\
\hline & Viktoras Rinkevičius & Lithuanian Farmers' and Greens' Union (major party/ centre-left) \\
\hline & Tomas Tomilinas & Lithuanian Farmers' and Greens' Union (major party/ centre-left) \\
\hline & $\begin{array}{l}\text { Lietuvos Žemès Ūkio } \\
\text { Taryba }\end{array}$ & \\
\hline & Rasa Petrauskienė & $\begin{array}{l}\text { Homeland Union-Lithuanian Christian Democrats (opposition/centre } \\
\text { right) }\end{array}$ \\
\hline & $\begin{array}{l}\text { Algimantas } \\
\text { Salamakinas }\end{array}$ & Social Democratic Party of Lithuania (opposition/centre-left) \\
\hline & Žemdirbių Savivalda & \\
\hline
\end{tabular}




\section{References}

1. Alons, G. (2017). Environmental policy integration in the EU's common agricultural policy: greening or greenwashing?. Journal of European Public Policy, Vol.24, No.11, p.1604-1622.

2. Brosius, J.P. (1999). Green dots, pink hearts: displacing politics from the Malaysian rain forest. American Anthropologist, Vol.101, No.1, p.36-57.

3. Bulmer, S. J. (2011). New institutionalism and the governance of the Single European Market. Journal of European Public Policy, Vol.5, No.3, p.365-386.

4. Daugbjerg, C., Feindt P. H. (2017). Post-exceptionalism in public policy: transforming food and agricultural policy. Journal of European Public Policy, Vol.24, No.11, p..1565-1584.

5. Erjavec, K., Erjavec, E. (2015). 'Greening the CAP' - Just a fashionable justification? A discourse analysis of the 2014-2020 CAP reform documents. Food Policy No.51, p.53-62.

6. Fabiani S., et al. (2020). Water energy food nexus approach for sustainability assessment at farm level: An experience from an intensive agricultural area in central Italy. Environmental Science and Policy, No.104, p.1-12.

7. Feindt, P. H., Oels, A. (2005). Does discourse matter? Discourse analysis in environmental policy-making. Journal of Environmental Policy \& Planning, Vol.7, No.3, p.161-173.

8. Foucault, M. (1977). Discipline and Punishment. London: Tavistock, 1977.

9. Foucault, M. (1990). The History of Sexuality (Vol. 1). New York: A Division of Random House, 1990.

10. Foucault, M. (1998). The Will to Knowledge: the history of sexuality. London: Penguin Books, 1998.

11. Foucault, M. Afterword: the subject in power, In H. L. Dreyfus \& P. Rabinow (Eds.), (1982). Michel Foucault: beyond structuralism and hermeneutics. Chicago: University of Chicago Press, 1982, p. 208-225.

12. Foucault, M. The Order of Things: An Archeology of the Human Sciences. London: Psychology Press, 2002.

13. Grant, W. (1995). Is agricultural policy still exceptional?. The Political Quarterly, No.66, p.156-169.

14. Greer, A. (2017). Post-exceptional politics in agriculture: an examination of the 2013 CAP reform. Journal of European Public Policy, 2017, Vol.24, No.11, p.1585-1603.

15. Hajer, M. (1995). The Politics of Environmental Discourse: Ecological Modernisation and the Policy Process. Oxford: Oxford University Press, 1995.

16. Hajer, M. (2005). Rebuilding ground zero. The politics of performance. Planning theory \& practice, Vol.6, No.4, p.448.

17. Hajer, M. (2006). Doing Discourse Analysis: Coalitions, Practices, Meaning, In M. van den Brink \& T. Metze (Eds.) Words matter in policy and Planning - Discourse Theory and Method in the Social Sciences. Netherlands: Geographical Studies, Utrecht: KNAG / Nethur, 2006, p.65-74.

18. Hall, S. (1992). The West and the Rest, In Hall, S., \& Gieben, B. (Eds.), Formations of modernity. Cambridge: Polity Press, 1992, p. 275-331.

19. Juntti, M. (2006). Riding the green wave in the European agricultural sector? A discourse analysis of the new cross compliance mechanism (CSERGE Working Paper EDM 06-15), 2006.

20. Knudsen, A.C.L. (2009). Farmers on Welfare. The Making of Europe's Common Agricultural Policy, Ithaca and London: Cornell University Press, 2009.

21. Laclau, E., C. Mouffe. (1985). Hegemony and Socialist Strategy:Towards a Radical Democratic Politics, London: Verso, 1985.

22. Sheingate, A. et al. (2017). Post-exceptionalism and corporate interests in US agricultural policy. Journal of European Public Policy, Vol.24, No.11, p.1641-1657. 
23. Skogstad, G. (1998). Ideas, Paradigms and Institutions: Agricultural Exceptionalism in the European Union and the United States. Governance: An International Journal of Policy and Administration, Vol.11, No.4, p.463-490.

24. Tosun, J. (2017). Party support for post-exceptionalism in agri-food politics and policy: Germany and the United Kingdom compared. Journal of European Public Policy, 2017, Vol.24, No.11, p.1623-1640.

25. Winkel, G., Leipold, S. (2016). Demolishing Dikes: Multiple Streams and Policy Discourse Analysis. Policy Studies Journal, Vol.44, No.1, p.111

\section{Jonė Vitkauskaitė-Ramanauskienè}

\section{Politikos išskirtinumas: idèjų sistemos, reguliuojančios žemès ūkio sektorių Lietuvoje, analizė}

\section{Anotacija}

Straipsnyje analizuojama dviejų diskursų - žemės ūkio politikos išskirtinumo ir žemès ūkio politikos post - išskirtinumo Lietuvos kontekste - sąveika. Tyrimo metu atlikta parlamentinès diskusijos dèl 2019 metų rudenį ūkininkų protestus sukèlusių politinių priežasčių, interpretacinė diskurso analizè. Nustatyta, kad LR vykdomosios valdžios siūlyti šalies ūkio mokestinio reguliavimo pokyčiai buvo bandymas deprioretizuoti žemès ūkio sektorių, lyginant su kitais ekonomikos sektoriais. Tačiau, nežiūrint to, žemès ūkio politikos išskirtinumo diskurso dominavimas išliko traktuojant siūlomus politikos pokyčius, kaip visuomenei nepriimtinus, moraliai neteisingus; ịvardijant žemės ūkio sektorių „netinkamu“ mokesčių rinkimui o aplinkosaugos priemones finansine našta.

Tyrime daroma išvada, kad žemès ūkio, kaip ekonomikos sektoriaus, išskirtinumo dominavimas yra diskursyvi kliūtis trukdanti žemès ūkio politiką optimaliau (efektyviau) suderinti (susieti) su aplinkosaugos tikslų ịgyvendinimu.

Jone Vitkauskaité-Ramanauskiené - Graduate of M.A. in Environmental social science at Stockholm University. Consultant at 'Center for environmental policy'.

E-mail: jonevitkauskaite@gmail.com

Jonè Vitkauskaitè-Ramanauskiené - Stokholmo universiteto Aplinkos ir socialinių mokslų magistrè, bei Aplinkos teisès centro konsultantè.

El. paštas: jonevitkauskaite@gmail.com 